\title{
Microbiological characteristics of meliponine honey marketed in the State of Paraná - Brazil
}

Características microbiológicas do mel meliponineos comercializados no Estado do Paraná - Brasil Características microbiológicas de la miel de meliponina comercializada en el Estado de Paraná Brasil

Received: 12/20/2020 | Reviewed: 12/27/2020 | Accept: 12/29/2020 | Published: 01/03/2021

Rejane Stubs Parpinelli

ORCID: https://orcid.org/0000-0003-1467-4287

State University of Maringa, Brazil

E-mail: rejanestubs@gmail.com

Erica Gomes de Lima

ORCID: https://orcid.org/0000-0001-9126-8456

State University of Maringa, Brazil E-mail: erica_zootecnista@hotmail.com

Fernando Antônio Anjo ORCID: https://orcid.org/ 0000-0001-6886-0304

State University of Maringa, Brazil

E-mail: fernandoaanjo@hotmail.com

Lucilene de Mattos Almeida

ORCID: https://orcid.org/0000-0001-5940-5668 State University of Maringa, Brazil E-mail: mattos.zootecnia@gmail.com

Paulo Henrique Março

ORCID: https://orcid.org/0000-0002-8953-066X Federal University of Technology, Brazil E-mail: paulohmarco@gmail.com

Vagner de Alencar Arnaut de Toledo ORCID: https://orcid.org/0000-0003-1814-9703 State University of Maringa, Brazil E-mail: vagner_abelha@yahoo.co.uk

\begin{abstract}
Meliponine is a honey with particular characteristics; it has a high percentage of humidity, which can favor the development of microorganisms, thereby causing changes in the quality of the product. The objective of this study was to evaluate the microbiological characteristics of meliponine honey produced by different species and marketed in the State of Paraná-Brazil. The sample unit was composed of honey of Tetragonisca angustula $(\mathrm{n}=15)$, Scaptotrigona bipunctata $(\mathrm{n}=05)$, Melipona quadrifasciata quadrifasciata $(\mathrm{n}=05)$ and Melipona bicolor schencki $(\mathrm{n}$ =01). The following microbiological parameters were evaluated: counts of total and thermotolerant coliforms, fungi count and detection of Salmonella spp. Principal component analysis (PCA) was used to evaluate the possible relationships among species, locality and type of microorganism. For microorganisms of the total coliform group, $15.38 \%$ of the analyzed samples had values $>3 \mathrm{MPN} / \mathrm{g}$. The presence of thermotolerant coliforms was observed in $7.69 \%$ of the samples, all of which were T. angustula samples. For fungi counts, $100.00 \%$ of the analyzed samples had values within the established range created by the Agricultural Defense Agency of Paraná. The presence of Salmonella spp. was not observed in any of the samples evaluated. The amount of water in the honey is related to the location of the apiary and edaphoclimatic factors. Adoption of good handling practices by beekeepers is indispensable for the safety of the final product.
\end{abstract}

Keywords: Microbiological quality; Coliforms; Fungi; Salmonella; PCA.

\section{Resumo}

Os meliponíneos elaboram um mel diferenciado com características particulares, apresenta elevado percentual de umidade o que pode favorecer o desenvolvimento de microrganismo ocasionando alterações na qualidade do produto. O objetivo deste estudo foi avaliar as características microbiológicas do mel de meliponíneos produzido por diferentes espécies e comercializado no Estado do Paraná-Brasil. A unidade amostral foi composta de mel de Tetragonisca angustula $(\mathrm{n}=15)$, Scaptotrigona bipunctata $(\mathrm{n}=05)$, Melipona quadrifasciata quadrifasciata ( $\mathrm{n}=05)$ e Melipona bicolor schencki $(\mathrm{n}=01)$. Parâmetros microbiológicos foram avaliados: contagem de coliformes totais e 
termotolerantes, contagem de fungos e detecção de Salmonella spp. A análise de componentes principais - ACP foi utilizada para avaliar as possíveis relações entre espécie, localidade e tipo de microrganismo. Para microrganismos do grupo coliformes totais, 15,38\% das amostras analisadas apresentaram valores $>3 \mathrm{NMP} / \mathrm{g}$. Em 7,69\% das amostras foi observado a presença de coliformes termotolerantes, sendo todas amostras de T. angustula. Para contagem de fungos, $100,00 \%$ das amostras analisadas apresentaram valores dentro do estabelecido pela Agência de Defesa Agropecuária do Paraná. Não foi observado a presença de Salmonella spp em nenhuma das amostras avaliadas. Algumas amostras se assemelharam segundo a espécie produtora e a quantidade de água no mel é relacionada com a localização do meliponário, devido a fatores edafoclimáticos. Adoção de boas práticas de manipulação pelos meliponicultores se tornam indispensáveis para conferir segurança alimentar ao produto final.

Palavras-chave: Qualidade microbiológica; Coliformes; Fungos; Salmonella; ACP.

\section{Resumen}

La meliponíne produce una miel diferenciada con características particulares, presenta un alto porcentaje de humedad, lo que puede favorecer el desarrollo de microorganismos provocando cambios en la calidad del producto. El objetivo de este estudio fue evaluar las características microbiológicas de la miel de meliponíne producida por diferentes especies y comercializada en el Estado de Paraná-Brazil. La unidad de muestra estuvo compuesta por miel de Tetragonisca angustula $(\mathrm{n}=15)$, Scaptotrigona bipunctata $(\mathrm{n}=05)$, Melipona quadrifasciata quadrifasciata $(\mathrm{n}=05)$ y Melipona bicolor schencki $(\mathrm{n}=01)$. Se evaluaron parámetros microbiológicos: recuento de coliformes totales y termotolerantes, recuento de hongos y detección de Salmonella spp. Análisis de componentes principales: se utilizó ACP para evaluar las posibles relaciones entre especies, localidad y tipo de microorganismo. Para los microorganismos del grupo de coliformes totales, el 15,38\% de las muestras analizadas presentaron valores $>3$ NMP/g. En el 7.69\% de las muestras se observó la presencia de coliformes termotolerantes, siendo todas muestras de T. angustula. Para contar hongos, el 100,00\% de las muestras analizadas presentaron valores dentro de lo establecido por la Agencia de Defensa Agropecuaria de Paraná. No se observó presencia de Salmonella spp en ninguna de las muestras evaluadas. Algunas muestras fueron similares según la especie productora y la cantidad de agua en la miel está relacionada con la ubicación del meliponario, debido a factores edafoclimáticos. La adopción de buenas prácticas de manipulación por parte de los productores de miel es fundamental para garantizar la seguridad alimentaria del producto final.

Palabras clave: Calidad microbiológica; Coliformes; Hongos; Salmonella; ACP.

\section{Introduction}

Honey is a natural, healthy and clean product that naturally contains microorganisms at minimum levels that provide subsidies for its control in industry and its natural characteristics (Bogdanov, 2009). Containing a distinct and unique microflora, honey has a high antimicrobial activity that is generally related to physical factors such as osmolarity, chemicals, and the presence of volatile compounds and hydrogen peroxide. The enzyme glucose oxidase and phenolic compounds are a natural barrier to the development of microorganisms in honey due to their oxidizing characteristics (Eteraf-Oskouei \& Najafi, 2013).

The microbiota present in honey can be divided into two microorganisms' groups. The microorganisms inherent to honey, which are the primary source of contamination, are bacterial spores, molds and yeasts that, under normal conditions of humidity, do not interfere with honey quality. There is secondary contamination directly related to the extraction, manipulation and processing of the product. This microbiota is one of the main criteria for evaluating product quality, along with other physical, chemical and sensory characteristics (Silva et al., 2017).

The total coliforms group is composed of non-sporulating, gram-negative bacteria that are, lactose fermenters, with acid and gas production at temperatures ranging between $32^{\circ}$ and $37^{\circ} \mathrm{C}$. The thermotolerant coliforms, whose natural habitat is the intestinal tract of warm-blooded animals, may be present in other environments such as water and vegetables, and they demonstrate whether the food has had contact with fecal material (Sereia et al., 2017).

The presence of microorganisms in honey may be variable and depend on floral origin, moisture, harvesting techniques and storage temperature (Al-Waili, Salom, Al-Ghamdi, \& Ansari, 2012). The quality of the honey is related to the hygiene practices of the producer, but it is also related to the hygiene habits of the bees. Many species land in fecal matter 
(Nogueira-Neto, 1997), which can cause a change in the quality of the final product, reducing shelf-life or rendering the product unfit for human consumption.

The conservation techniques (refrigeration, pasteurization, dehydration and fermentation) adopted by beekeepers are empirical. Brazilian and international regulations do not include microbiological quality parameters for meliponine honey (Brasil, 2000; FAO, 2001). The absence of specific legislation and the diversity of meliponine species in Brazil reinforces the need to obtain more specific information on the physicochemical and microbiological characteristics of honey for the establishment of quality and identity standards (Carvalho et al., 2013).

The Technical Regulation of Identity and Quality of Honey of Stingless bees for the state of Parana was established by the Agency of Agricultural and Livestock Defense of Parana, Ordinance $\mathrm{N}^{\circ} 63$ of March 10, 2017, based on results from studies conducted in the region (Adapar, 2017). This standard determines which parameters should be considered to assess the quality of honey produced by stingless bees. The objective of this study was to evaluate the microbiological characteristics of meliponine honey produced by different species and marketed in the State of Paraná.

\section{Materials and Methods}

\subsection{Collection of samples}

The samples were obtained from six distinct regions (Figure 1) of the State of Paraná-Brazil, comprising 14 different cities (Table 1 and Figure 1). We analyzed 26 samples of meliponine honey from the following species: T. angustula $(\mathrm{n}=15)$, S. bipunctata $(\mathrm{n}=5)$, M. q. quadrifasciata $(\mathrm{n}=5)$ and M. b. schencki $(\mathrm{n}=1)$.

The samples were collected from their colonies according to the practical methods of harvesting of each producer. After harvesting, the honey was packed in properly sterilized polypropylene or glass jars and stored under refrigeration at a temperature of $5^{\circ} \mathrm{C}$ until the start of the analysis.

Table 1. Geographical coordinates of the cities in which the honey samples were collected.

\begin{tabular}{lll}
\hline Cities of Paraná - Brazil & Geographical coordinates & State Region \\
\hline Guaraqueçaba & $25^{\circ} 18^{\prime} 25^{\prime \prime} \mathrm{S} 48^{\circ} 19^{\prime} 44^{\prime \prime} \mathrm{W}$ & Coast from Paraná \\
São José dos Pinhais & $25^{\circ} 32^{\prime} 06^{\prime \prime} \mathrm{S} 49^{\circ} 12^{\prime} 21^{\prime \prime} \mathrm{W}$ & Curitiba/metropolitan area \\
Mandirituba & $25^{\circ} 46^{\prime} 44^{\prime \prime} \mathrm{S} 49^{\circ} 19^{\prime} 33^{\prime \prime} \mathrm{W}$ & Curitiba/metropolitan area \\
Ponta Grossa & $25^{\circ} 05^{\prime} 42^{\prime \prime} \mathrm{S} 50^{\circ} 09^{\prime} 43^{\prime \prime} \mathrm{W}$ & Campos gerais \\
Ortigueira & $24^{\circ} 12^{\prime} 28^{\prime \prime} \mathrm{S} 50^{\circ} 56^{\prime} 56^{\prime \prime} \mathrm{W}$ & Campos gerais \\
Cambará & $23^{\circ} 02^{\prime} 45^{\prime \prime} \mathrm{S} 50^{\circ} 04^{\prime} 26^{\prime \prime} \mathrm{W}$ & North \\
Maringá & $23^{\circ} 25^{\prime} 30^{\prime \prime} \mathrm{S} 51^{\circ} 56^{\prime} 20^{\prime \prime} \mathrm{W}$ & Northwest \\
Marialva & $23^{\circ} 29^{\prime} 06^{\prime \prime} \mathrm{S} 51^{\circ} 47^{\prime} 31^{\prime \prime} \mathrm{W}$ & Northwest \\
Floresta & $23^{\circ} 35^{\prime} 56^{\prime \prime} \mathrm{S} 52^{\circ} 04^{\prime} 51^{\prime \prime} \mathrm{W}$ & Northwest \\
Jussara & $23^{\circ} 37^{\prime} 15^{\prime \prime} \mathrm{S} 52^{\circ} 28^{\prime} 08^{\prime \prime} \mathrm{W}$ & Northwest \\
Tuneiras do Oeste & $23^{\circ} 52^{\prime} 15^{\prime \prime} \mathrm{S} 52^{\circ} 52^{\prime} 33^{\prime \prime} \mathrm{W}$ & Northwest \\
Perobal & $23^{\circ} 53^{\prime} 45^{\prime \prime} \mathrm{S} 53^{\circ} 24^{\prime} 36^{\prime \prime} \mathrm{W}$ & Northwest \\
Pérola & $23^{\circ} 48^{\prime} 18^{\prime \prime} \mathrm{S} 53^{\circ} 41^{\prime} 02^{\prime \prime} \mathrm{W}$ & Northwest \\
Marechal C. Rondon & $24^{\circ} 33^{\prime} 21^{\prime \prime} \mathrm{S} 54^{\circ} 03^{\prime} 25^{\prime \prime} \mathrm{W}$ & West/Itaipu \\
\hline
\end{tabular}

Source: Authors. 
Figure 1. Geographical distribution of cities where honey samples were collected.

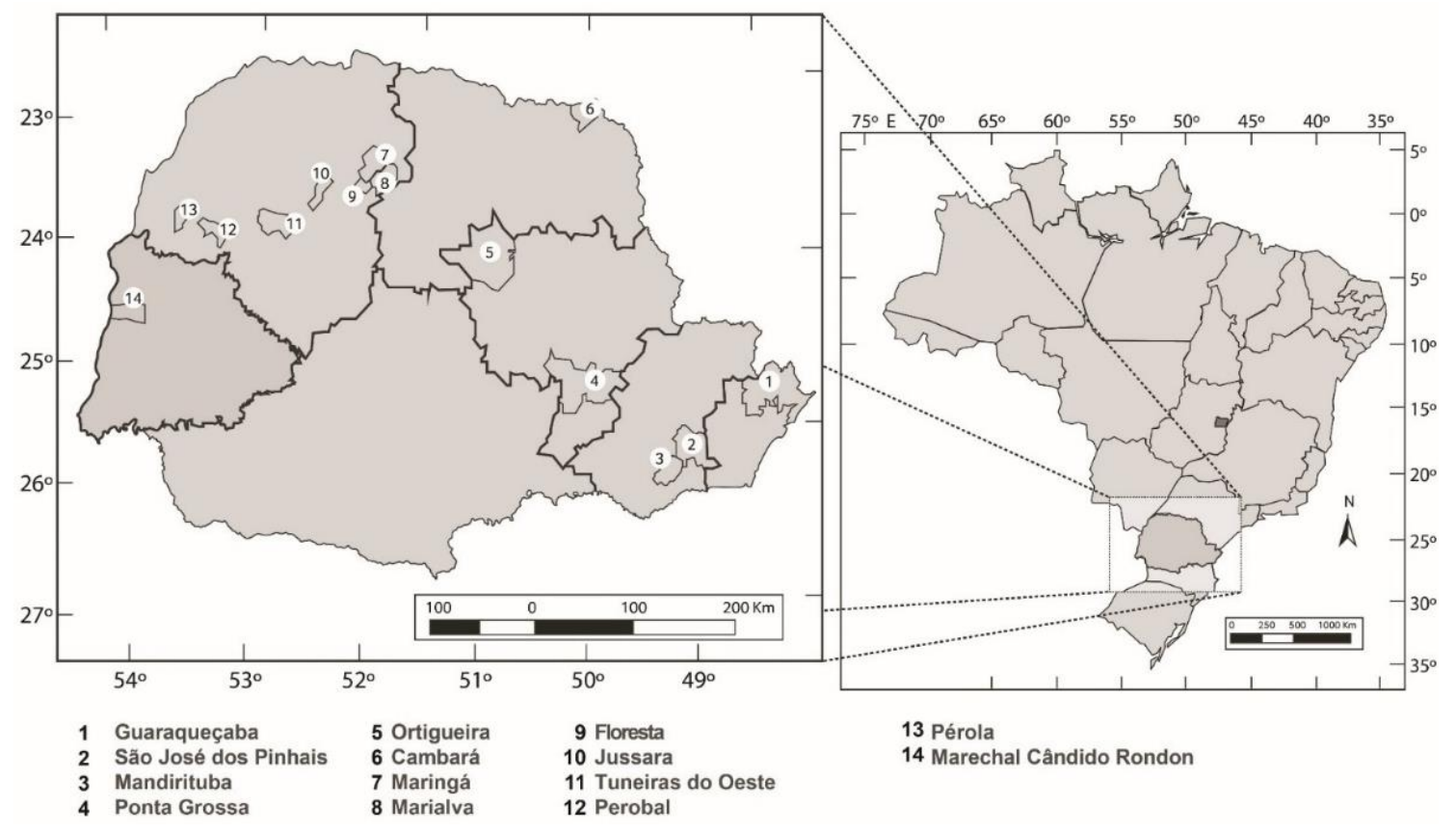

Source: Authors.

\subsection{Microbiological analysis}

Following methods described by APHA's international standards, the APHA technical committee on microbiological methods for food (Salfinger \& Tortorello, 2015) and the data collection techniques described by Pereira, Shitsuka, Parreira, \& Shitsuka, (2018), the following microbiological analysis were performed: counting of total and thermotolerant coliforms, fungi counting and Salmonella spp. counts (Brasil, 2003). Aseptically, $25 \mathrm{~g}$ of honey were added to $225 \mathrm{~mL}$ of peptone water (Himedia, Mumbai, India) (0.1\%) and homogenized. Subsequent decimal dilutions were prepared in sterile peptone water and analyzed by counting plates or by The Most Probable Number technique (MPN), depending on the type of microorganism.

\subsubsection{Total coliforms}

The Most Probable Number technique (MPN/g), obtained using Hoskins table analysis (APHA, AWWA, WEF, 2012), was used. The presumptive test was initially carried out using a series of the three dilutions. One mL was inoculated into a series of three tubes using lauryl sulphate tryptose broth - LST (Acumedia, Lansing, EUA) to determine total coliforms. The tubes were incubated at $35^{\circ} \mathrm{C}$ for $48 \mathrm{~h}$. The confirmatory test included inoculating three loops of each LST-positive tube into tubes containing brilliant green bile broth - BGBB (Biomark, Pune, India) at $35^{\circ} \mathrm{C}$ for $48 \mathrm{~h}$. The presence of gas and turbidity in the environment defines this analysis as positive.

\subsubsection{Thermotolerant coliforms}

Escherichia coli broth - EC (Acumedia, Lansing, EUA) was used for the detection of thermotolerant coliforms. Three loops of each LST-positive tube were transferred to EC broth and incubated at $45^{\circ} \mathrm{C}$ for $48 \mathrm{~h}$. The presence of gas and turbidity in the environment defines this analysis as positive. 


\subsubsection{Fungi counts}

For fungi counts, $1.0 \mathrm{~mL}$ of the dilutions were plated using potato dextrose agar - PDA (Acumedia, Lansing, USA) acidified with tartaric acid (Synth, São Paulo, Brazil) at $10.00 \%$ to pH 3.5. The incubation was carried out in a bacteriological oven (TE-392/2, Tecnal, Brazil) for seven days. After this time, the plates were removed from the oven, and the number of colony forming units (CFU/g) was counted.

\subsubsection{Analysis of Salmonella spp.}

The sample was prepared according to section 2.3.1 and incubated for $20 \mathrm{~h}$ at $36^{\circ} \mathrm{C}$ in a bacteriological oven. Aliquots of $0.1 \mathrm{~mL}$ of the pre-enriched samples were transferred to separate tubes containing $10.0 \mathrm{~mL}$ of rappaport vassiliadis soy broth - RVS (Acumedia, Lansing, USA) and $10.0 \mathrm{~mL}$ of selenite cystine broth - SC (Biomark, Pune, India) and incubated at $41^{\circ} \mathrm{C}$ for $24 \mathrm{~h}$ in a water bath (Q226M2, Quimis, Brasil). Isolation of typical colonies of Salmonella spp. was performed on solid medium: brilliant green phenol red lactose sucrose agar - BLPS (Acumedia, Lansing, USA) and hektoen enteric agar - HE (Acumedia, Lansing, USA).

\subsection{Moisture and water activity}

The moisture was determined using a bench refractometer (WY1A; ABBE, USA) with the aid of a Chataway table (AOAC, 1990; Bogdanov, 2009). A digital meter (LabSwift; Novasina, Switzerland) using a dew point fixation technique in an encapsulated mirror $=$ measured the water activity.

\subsection{Statistical analysis}

The multivariate statistical method of principal component analysis using Matrix Laboratory Matlab ${ }^{\circledR}$ software, version R2013b, was used to verify the similarities and differences among the data obtained from the samples (Pestana \& Gageiro, 2014). To make a general evaluation of the data, it was necessary to use the main components analysis method for determining which samples were similar (scores) and which motives or charges characterized separation (loadings). Eight major components were used to explain $97.43 \%$ of the total variance of the data. This technique aims to reduce the number of variables analyzed. All determinations were performed in triplicate.

\section{Results and Discussion}

\subsection{Total and thermotolerant coliforms}

It was observed in Table 2, that $15.38 \%$ and $7.69 \%$ of the analyzed samples had $>3 \mathrm{MPN} / \mathrm{g}$ values of total and thermotolerant coliforms, respectively. All of these samples originated from T. angustula. This species of bee is considered one of the most hygienic among the meliponineos, but this does not exclude the possibility that this bee landed on undesirable materials (Nogueira-Neto, 1997). Results > $3 \mathrm{MPN} / \mathrm{g}$ can be attributed to failures in good practices of manipulation by the beekeeper in relation to the samples. Some species of meliponine, such as M. subnitida and T. spinipes, exhibit anti-hygienic habits, with direct records of the collection of fecal material (Nogueira-Neto, 1997). There are reports of visits of S. bipunctata and M. q. quadrifasciata to vertebrate excrement (Nogueira-Neto, 1997). However, all honey samples from these species had values $<3 \mathrm{MPN} / \mathrm{g}$ for thermotolerant coliforms. 
Table 2. Microbiological quality of honey samples grouped by meliponine species from regions of the State of Paraná, Brazil.

\begin{tabular}{|c|c|c|c|c|c|c|c|}
\hline \multirow[b]{2}{*}{ Species } & \multirow[b]{2}{*}{ Sample } & \multicolumn{2}{|c|}{ Coliforms (MPN/g) } & \multirow[b]{2}{*}{$\begin{array}{l}\text { Fungi } \\
\text { (CFU/g) }\end{array}$} & \multirow[b]{2}{*}{$\begin{array}{l}\text { Salmonella } \\
(25 \mathrm{~g})\end{array}$} & \multirow[b]{2}{*}{$\begin{array}{l}\text { Moist } \\
(\%)\end{array}$} & \multirow[b]{2}{*}{ Aw } \\
\hline & & $35^{\circ} \mathrm{C}$ & $45^{\circ} \mathrm{C}$ & & & & \\
\hline & 1 & $<3.00$ & 0.00 & $3.60 \times 10^{4}$ & Away & 24.07 & 0.69 \\
\hline \multirow[t]{14}{*}{ T. angustula } & 2 & 215.40 & 3.00 & $3.50 \times 10^{4}$ & Away & 24.87 & 0.72 \\
\hline & 3 & $<3.00$ & 0.00 & $8.10 \times 10^{4}$ & Away & 24.60 & 0.71 \\
\hline & 4 & $<3.00$ & 0.00 & $5.80 \times 10^{4}$ & Away & 24.73 & 0.71 \\
\hline & 5 & $<3.00$ & 0.00 & $5.40 \times 10^{4}$ & Away & 26.87 & 0.73 \\
\hline & 10 & $<3.00$ & 0.00 & $2.00 \times 10^{4}$ & Away & 24.07 & 0.71 \\
\hline & 11 & $<3.00$ & 0.00 & $7.60 \times 10^{4}$ & Away & 24.60 & 0.71 \\
\hline & 12 & $<3.00$ & $<3.00$ & $3.40 \times 10^{4}$ & Away & 25.53 & 0.72 \\
\hline & 13 & $<3.00$ & 0.00 & $1.30 \times 10^{4}$ & Away & 23.27 & 0.70 \\
\hline & 15 & 10.67 & $<3.00$ & $1.10 \times 10^{4}$ & Away & 24.47 & 0.73 \\
\hline & 16 & 3.00 & $<3.00$ & $2.30 \times 10^{4}$ & Away & 24.33 & 0.70 \\
\hline & 18 & $<3.00$ & $<3.00$ & $2.20 \times 10^{4}$ & Away & 25.53 & 0.71 \\
\hline & 20 & $<3.00$ & $<3.00$ & $2.60 \times 10^{4}$ & Away & 25.13 & 0.72 \\
\hline & 24 & 125.30 & 23.00 & $3.80 \times 10^{4}$ & Away & 24.33 & 0.72 \\
\hline & 25 & $<3.00$ & 0.00 & $3.60 \times 10^{4}$ & Away & 23.93 & 0.72 \\
\hline Mean & & 24.36 & 2.13 & $3.75 \times 10^{4}$ & 0.00 & 24.69 & 0.71 \\
\hline Median & & 1.00 & 0.00 & 3.50 & 0.00 & 24.60 & 0.71 \\
\hline Standard deviation & & 61.72 & 5.84 & 2.12 & 0.00 & 0.85 & 0.01 \\
\hline \multirow[t]{5}{*}{ S. bipunctata } & 7 & $<3$ & 0.00 & $4.70 \times 10^{4}$ & Away & 31.13 & 0.76 \\
\hline & 17 & $<3$ & $<3$ & $2.50 \times 10^{4}$ & Away & 27.40 & 0.73 \\
\hline & 19 & $<3$ & $<3$ & $2.70 \times 10^{4}$ & Away & 25.67 & 0.71 \\
\hline & 23 & $<3$ & $<3$ & $1.00 \times 10^{4}$ & Away & 25.80 & 0.71 \\
\hline & 26 & $<3$ & 0.00 & $3.50 \times 10^{4}$ & Away & 26.73 & 0.73 \\
\hline Mean & & 1.20 & 0.60 & $2.90 \times 10^{4}$ & 0.00 & 27.35 & 0.73 \\
\hline Median & & 1.00 & 1.00 & 2.70 & 0.00 & 26.73 & 0.73 \\
\hline Standard deviation & & 0.45 & 0.55 & 1.33 & 0.00 & 2.23 & 0.02 \\
\hline \multirow[t]{5}{*}{ M. q. quadrifasciata } & 6 & $<3$ & 0.00 & $4.40 \times 10^{4}$ & Away & 34.07 & 0.79 \\
\hline & 8 & $<3$ & 0.00 & $2.50 \times 10^{4}$ & Away & 25.40 & 0.70 \\
\hline & 14 & $<3$ & 0.00 & $8.40 \times 10^{4}$ & Away & 27.67 & 0.72 \\
\hline & 21 & $<3$ & 0.00 & $3.10 \times 10^{4}$ & Away & 38.73 & 0.84 \\
\hline & 22 & $<3$ & 0.00 & $1.30 \times 10^{4}$ & Away & 41.80 & 0.85 \\
\hline Mean & & 1.00 & 0.00 & $3.94 \times 10^{4}$ & 0.00 & 33.53 & 0.78 \\
\hline Median & & 1.00 & 0.00 & 3.10 & 0.00 & 34.07 & 0.79 \\
\hline Standard deviation & & 0.00 & 0.00 & 2.73 & 0.00 & 7.00 & 0.07 \\
\hline M. b. schencki & 9 & $<3.00$ & 0.00 & $4.20 \times 10^{4}$ & Away & 33.13 & 0.78 \\
\hline
\end{tabular}

Moist (\%): moisture; Aw: water activity. Source: Authors.

Honey samples from M. fasciculata from the state of Maranhão, Brazil, had low counts of total and thermotolerant coliforms that were within the limits established by the Mercosul countries and the State Legislation (10² MPN/g). This 
suggested good practices in relation to the manipulation of honey (Adapar, 2017; Fernandes, Rosa, \& Conti-Silva, 2018; Mercosul, 1994). Good practices may be associated with the absence of microorganisms from the coliform group in trigonine honey samples in the State of Bahia, Brazil (Souza, Marchini, Oda-Souza, Carvalho, \& Alves, 2009) and honey samples from the M. compressipes, M. subnitida and M. scutellaris species from the State of Piauí, Brazil (Monte et al., 2013; Souza, Marchini, Oda-Souza, et al., 2009). In samples of honey from Melipona spp. in the state of Amazonas, 33.33\% had positive results for coliforms at $35^{\circ} \mathrm{C}$ and $45^{\circ} \mathrm{C}$. The foraging flight areas of bees may influence the microbiological quality of honey (Matos, Nunes, Mota \& Laureano, 2011).

The positive results verified in this study for the coliform group may be related to the fact that the quantification of these microorganisms in honey represents accurate data in the samples but not in the environment (Souza, Marchini, OdaSouza, et al., 2009). The samples that are positive for thermotolerant coliforms may suggest the presence of other microorganisms that accompany Escherichia coli in feces. The presence of microorganisms in food is an indicator of the possible presence of pathogenic microorganisms that are difficult to identify (Gerba, 2015).

\subsection{Fungi counts}

All samples of honey analyzed had values above those allowed in the Mercosur countries (Mercosul, 1994) (Table 2), in which honey can contain a maximum of $100 \mathrm{CFU} / \mathrm{g}$, but the values were within the limit established by Paraná legislation $\left(10^{4} \mathrm{CFU} / \mathrm{g}\right)$ (Adapar, 2017). The maximum and minimum values were verified in sample 14 (M. q. quadrifasciata) and 23 ( $S$. bipunctata).

The origin of fungi in honey is often naturally occurring and probably comes from primary sources when nectar is being harvested, stored and matured. Fungi may also be incorporated during processing, as spores can be found in the air (AlWaili et al., 2012). Usually, this flora is found in concentrations below $100 \mathrm{CFU} / \mathrm{g}$, because they are controlled by industrial practices that prevent fermentation (Mercosul, 1994).

It is recommended that meliponine honey should be collected aseptically to prevent possible external contamination (Schlabitz, Silva, \& Souza, 2010). Apiaries in unhealthy environments and environmental variables may be responsible for counts of microorganisms above the standards in analyzed samples.

When evaluating the microbiological quality of 14 samples of honey produced by five species of stingless bees in the State of Bahia (Tetragonisca, Frieseomelitta, Nannotrigona, Partamona and Scaptotrigona), Souza, Marchini, Oda-Souza, et al., (2009) reported that $50 \%$ of the samples had results above the maximum established by the Mercosul Resolution. Fernandes et al., (2018), analyzing 40 samples of M. fasciculata honey from the State of Maranhão, verified that 5\% of the samples had presented results above the maximum established by the Mercosur Resolution. However, under current state legislation (Adapar, 2017), 100\% of the analyzed samples were within the established limit and were suitable for human consumption.

Honey samples from T. angustula in the city of Misiones, Argentina, collected aseptically had differences in microbiological quality, with mean values for molds and yeasts of $1.05 \times 10^{3} \mathrm{CFU} / \mathrm{g}$ (Pucciarelli et al., 2014). Osmophilic yeasts are the microorganisms that influence the quality of honey. Yeasts are present due to acidic conditions of the medium and because they are not inhibited by high concentrations of sugar. This can lead to fermentation of the product, promoting the production of ethanol and carbon dioxide and generating unpleasant flavors (Tornuk et al., 2013).

\subsection{Salmonella spp.}

Salmonella is the most common cause of gastrointestinal disease, leading to serious consequences in children under 5 
years of age, the elderly over 65 years of age, and people with weakened immune systems. Outbreaks of salmonellosis detected in several parts of the world, and it is estimated that in the United States, 1 million foodborne diseases are caused by this microorganism (Mba-Jonas et al., 2018). In Canada, 87.500 domestic cases of food infection caused by Salmonella occur annually (Vrbova et al., 2018).

We did not identify Salmonella spp. in any of the analyzed samples (Table 2). In honey from M. compressipes, $M$. subnitida and M. scutellaris from the State of Piaú, Brazil, and in honey from T. angustula from the city of Misiones, Argentina, we did not detect Salmonella, suggesting the adoption of good management practices by the beekeeper, adequate facilities, and the use of disposable materials or stainless steel for the extraction, packaging and storage of honey (Monte et al., 2013).

\subsection{Moisture and water activity (Aw)}

Water is the main component of many foods and has influence on the food biochemical stability. The water excess found in meliponine honey is due to the low rate of dehydration of the nectar during the transformation process of honey (Monte et al., 2013). Meliponine honey may contain a moisture content above 20.00\% (Anacleto, Souza, Marchini, \& Moreti, 2009; Souza, Marchini, Oda-Souza, et al., 2009). Due to the moisture content the amount of free water (water activity) in this honey is also high. Water activity is one of the main factors that prevents or limits microbial development. Just as moisture is responsible for product stability, it modulates the microbial response and determines what kind of microorganism will develop in the product. Adverse conditions of Aw may cause osmotic stress and the sporulation of microorganisms, and under optimal water activity, conditions induce germination and growth. The production of secondary metabolites (toxins) is also affected by the Aw value of the medium.

An average of $29.65 \%$ moisture was observed, ranging from 23.27 to $41.80 \%$, in $T$. angustula sample 13 and $M$. quadrifasciata sample 22, respectively (Table 2). Samples of honey from T. angustula from the city of Misiones, Argentina, had moisture contents of $24.00 \%$ (Pucciarelli et al., 2014). In the Northeast region of Brazil, honey samples from M. subnitida had a humidity of $24.80 \%$ (de Almeida-Muradian et al., 2013). In another study carried out in the Southern region of Brazil, more specifically in Santa Catarina State, the honey samples of M. bicolor, M. quadrifasciata, S. bipunctata and T. angustula had a humidity of 30.08\%, 31.23\%, 29.77\% and 26.98\%, respectively (Batiston, Frigo, Stefani, Silva, \& Araujo, 2020).

The mean water activity observed in the samples was 0.75 , with a variation of 0.69 to 0.85 for $T$. angustula sample 1 and M. quadrifasciata sample 22, respectively (Table 2). Variations in water activity values were found between 0.65 and 0.69 for samples of meliponas in the state of Piauí (Monte et al., 2013) and from 0.66 to 0.85 for samples of meliponas from different localities in the state of Bahia, northeastern Brazil (Souza, Marchini, Dias, et al., 2009). Values varying from 0.59 to 0.82, with an average of 0.66, were identified in T. angustula honey samples collected in São Paulo, Brazil (Anacleto et al., 2009).

Despite the known influence of moisture and water activity on the growth of microorganisms in a medium, the moisture and water activity of the honey samples did not explain the positive results found for the coliform group, mainly the thermotolerant coliforms. These bacteria require a water activity greater than 0.91 for growth (Bogdanov, 2014; Damodaran, Parkin, \& Fennema, 2018), and the maximum Aw found in these analysis was 0.85. This is insufficient for the development of enteric pathogens, considering contamination post-processing of the product by unhygienic habits of the manipulator, which does not exclude the survival of these bacteria in the medium.

Due to the high water content of meliponine honey, the application of dehumidification techniques may be an option for conservation (Ramli et al., 2018). Without causing changes in quality and acceptability by consumers, this technique may help 
to prolong the shelf-life of the product (Carvalho et al., 2009).

\subsection{Principal component analysis}

Figure 2 presents the results of the principal component analysis by projection of principal component 1 , which accounts for $42.05 \%$ of the explained variance, against principal component 2, which accounts for $29.41 \%$ of the explained variance. This analysis separates samples with higher counts of coliforms (negative quadrant of component 1 and positive quadrant of component 2) that may be influenced by water and moisture activity (positive quadrant of component 1 and 2 ), and it also separates samples influenced by significant levels of fungi (negative quadrant of component 1 and 2). 
Figure 2. Correlations between microbiological characteristics and the description of the meliponine honey through principal component analysis. PC: principal component.

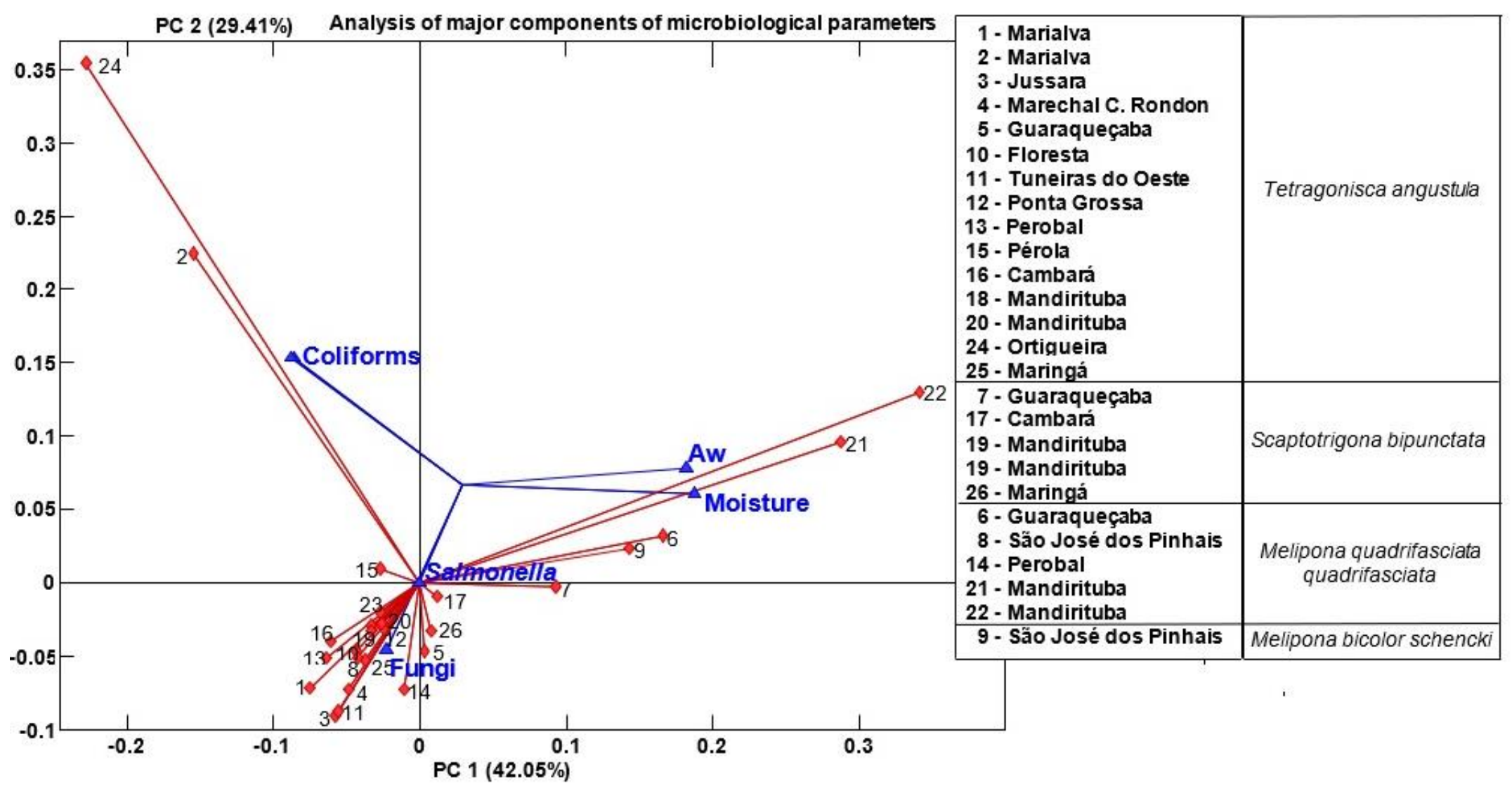

Source: Authors. 
Figure 2 also presents the projection of samples with the highest counts of coliforms (negative quadrant of component 1 and positive quadrant of component 2), represented by samples two, fifteen and twenty-four, both produced by T. angustula bees, from the cities of Marialva, Perobal and Ortigueira, respectively.

The positive quadrant of component 1 and component 2 included most of the samples from the genus Melipona due to the moisture content and water activity. We observed that samples six, twenty-one and twenty-two, all from honey of bees of the species M. q. quadrifasciata, and sample nine, from the species $M$. b. schencki, had high values of moisture content and water activity. We observed that samples twenty-one and twenty-two, both from Mandirituba, were the samples that had the highest moisture content and water activity, probably due to the location of the apiary near the coast. Sample six from Guaraqueçaba and sample nine from São José dos Pinhais were less affected than the others.

Samples influenced by significant fungi content were grouped in the negative quadrant of component 1 and component 2. Most of the samples showed significant fungi counts, and samples three, four, five, eleven and fourteen were the samples that had the highest counts (from T. angustula bees).

\section{Conclusions}

Most meliponine honey samples from different species and localities in the state of Paraná, Brazil, were considered suitable for commercialization. The location of an apiary can influence the type of microorganism present in the honey, and the adoption of good practices of manipulation in relation to the product, from the management of the hive to consumption, guarantees the quality of the product and allows supervision by the authorities.

Future investigations on physical and chemical analysis of stingless honey, in conjunction with scientific articles that address the same theme, can contribute to improving the productivity and quality of the honey produced, resulting in the advancement of food and nutritional security.

\section{Acknowledgments}

The authors acknowledge the CNPq (National Council for Scientific and Technological Development), process number 311663/2014-1 and 482947/2013-6, for the financial support.

\section{References}

Adapar, Agricultural Defense Agency of Paraná. Portaria nº 63 de 10 de março de 2017 - Estabelece o Regulamento Técnico de Identidade e Qualidade do Mel de Abelhas Sem Ferrão para o estado do Paraná. (2017).

Al-Waili, N., Salom, K., Al-Ghamdi, A., \& Ansari, M. J. (2012). Antibiotic, Pesticide, and Microbial Contaminants of Honey: Human Health Hazards. The Scientific World Journal, 2012, 1-9. https://doi.org/10.1100/2012/930849

Anacleto, D. D. A., Souza, B. D. A., Marchini, L. C., \& Moreti, A. C. D. C. C. (2009). Composição de amostras de mel de abelha Jataí (Tetragonisca angustula latreille, 1811). Ciência e Tecnologia de Alimentos, 29(3), 535-541. https://doi.org/10.1590/S0101-20612009000300013

AOAC. (1990). Official Methods of Analysis of AOAC International. In Association of Official Analysis Chemists International: Vol. II (pp. 1058-1059). https://doi.org/10.3109/15563657608988149

APHA, AWWA, WEF. (2012). Standard Methods for Examination of Water and Wastewater. Washington: American Public Health Association.

Batiston, T. F. T. P., Frigo, A., Stefani, L. M., Silva, A. S. Da, \& Araujo, D. N. (2020). Physicochemical composition and antimicrobial potential of stingless honey: a food of differentiated quality. Research, Society and Development, 9(10), e7099108223. https://doi.org/10.33448/rsd-v9i10.8223

Bogdanov, S. (2014). Honey in Medicine. Bee Product Science, (February), 1-24. https://doi.org/10.1055/s-0033-1359950 
Bogdanov, S. (2009). Harmonised Methods of the International IHC. In Bee Product Science,. https://doi.org/10.1007/s13398-014-0173-7.2

Brasil. (2000). Instrução Normativa 11 de 20 de outubro de 2000. Aprova o Regulamento Técnico de Identidade e Qualidade do Mel. Diário Oficial Da União, 23.

Brasil, Ministério da Agricultura, Pecuaria e Abastecimento. Secretaria de Defesa Agropecuaria. (2003). Instrução Normativa No 62 , de 26 de agosto de 2003. Oficializa os Métodos Analíticos Oficiais para Análises Microbiológicas para Controle de Produtos de Origem Animal e Água. Diário Oficial Da União.

Carvalho, C.A.L. de, Alves, R.M. de O., Souza, B. de A., Veras, S. de O., Alves, E.M., Sodré, G. da S. (2013). Stingless bees process honey and pollen in cerumen pots (P. V. D. Roubik., ed.). Venezuela.

Carvalho, C. A. L., Sodré, G. S., Fonseca, A. A. O., Alves, R. M. O., Souza, B. A., \& Clarton, L. (2009). Physicochemical characteristics and sensory profile of honey samples from stingless bees (Apidae: Meliponinae) submitted to a dehumidification process. Anais Da Academia Brasileira de Ciências, 81(1), 143149. https://doi.org/10.1590/S0001-37652009000100015

Damodaran, S., Parkin, K. L., \& Fennema, O. R. (2018). Química de los Alimentos de Fennema. In Quimica de Alimentos de Fennema.

de Almeida-Muradian, L. B., Stramm, K. M., Horita, A., Barth, O. M., da Silva de Freitas, A., \& Estevinho, L. M. (2013). Comparative study of the physicochemical and palynological characteristics of honey from Melipona subnitida and Apis mellifera. International Journal of Food Science \& Technology, 48(8), 1698-1706. https://doi.org/10.1111/ijfs.12140

Eteraf-Oskouei, T., \& Najafi, M. (2013). Traditional and modern uses of natural honey in human diseases: A review. Iranian Journal of Basic Medical Sciences. https://doi.org/10.22038/ijbms.2013.988

FAO. (2001). Revised Codex Standard for Honey. In Codex Alimentarius Commission.

Fernandes, R. T., Rosa, I. G., \& Conti-Silva, A. C. (2018). Microbiological and physical-chemical characteristics of honeys from the bee Melipona fasciculata produced in two regions of Brazil. Ciência Rural, 48(5). https://doi.org/10.1590/0103-8478cr20180025

Gerba, C. P. (2015). Indicator Microorganisms. In Environmental Microbiology (pp. 551-564). https://doi.org/10.1016/B978-0-12-394626-3.00023-5

Matos, I. T. S. R., Nunes M. T., Mota, D. A., Laureano, M. M. M., Hoshiba, M. A. (2011). Qualidade microbiológica do mel de Melipona sp. produzido na Amazônia Central (Parintis-AM, Brasil). Revista Verde de Agroecologia e Desenvolvimento Sustentável, 6(4), 91-95.

Mba-Jonas, A., Culpepper, W., Hill, T., Cantu, V., Loera, J., Borders, J., ... Neil, K. P. (2018). A Multistate Outbreak of Human Salmonella Agona Infections Associated With Consumption of Fresh, Whole Papayas Imported From Mexico-United States, 2011. Clinical Infectious Diseases, 1-6. https://doi.org/10.1093/cid/cix1094

Mercosul, M. C. do S. Resolução n. 15/94. Regulamento Técnico MERCOSUL de Identidade e Qualidade do Mel. , (1994).

Monte, A. M., Azevedo, M. L. X., Das Chagas Cardoso Filho, F., Rodrigues, A. M. D., De Moura, S. G., \& Muratori, M. C. S. (2013). Qualidade de méis de abelhas nativas sem ferrão do estado do piauí, brasil. Revista Brasileira de Medicina Veterinaria, 35(1), 48-54.

Nogueira-neto, P. (1997). Vida e Criação de Abelhas Indígenas Sem Ferrão. In Acta Amazonica.

Pereira, A. S., Shitsuka, D. M., Parreira, F. J., \& Shitsuka, R. (2018). Método Qualitativo, Quantitativo ou Quali-Quanti. In Metodologia da Pesquisa Científica. https://repositorio.ufsm.br/bitstream/handle/1/15824/Lic_Computacao_Metodologia-Pesquisa-Cientifica.pdf?sequence=1. Acesso em: 28 março 2020 .

Pestana, M. H., Gageiro, J. N. (2014). Análise de Dados para Ciências Sociais - A Complementariedade do SPSS (6th ed.). Lisboa. 
Pucciarelli, A. B., Schapovaloff, M. E., Kummritz, S., Señuk, I. A., Brumovsky, L. A., \& Dallagnol, A. M. (2014). Microbiological and physicochemical analysis of yateí (Tetragonisca angustula) honey for assessing quality standards and commercialization. Revista Argentina de Microbiología, 46(4), 325-332. https://doi.org/10.1016/S0325-7541(14)70091-4

Ramli, A. S., Basrawi, F., Ibrahim, T. K., Yusof, M. H. Bin, Oumer, A. N., Johari, N. A., ... Habib, K. (2018). Experimental analysis on a novel lowtemperature vacuum drying with induced nucleation technique for dewatering stingless bees honey. Drying Technology, $1-7$. https://doi.org/10.1080/07373937.2018.1444634

Salfinger, Y., \& Tortorello, M. Lou. (2015). Compendium of Methods for the Microbiological Examination of Foods. In Y. Salfinger \& M. Lou Tortorello (Eds.), Compendium of Methods for the Microbiological Examination of Foods. https://doi.org/10.2105/MBEF.0222

Schlabitz, C., Ferreira da Silva, S. A., \& Volken de Souza, C. F. (2010). Avaliação de parâmetros físico-químicos e microbiológicos em mel. Revista Brasileira de Tecnologia Agroindustrial, 4(1). https://doi.org/10.3895/S1981-36862010000100009

Sereia, M. J., Perdoncini, M. R. F. G., Março, P. H., Parpinelli, R. S., de Lima, E. G., \& Anjo, F. A. (2017). Techniques for the Evaluation of Microbiological Quality in Honey. Honey Analysis. https://doi.org/10.5772/67086

Silva, M. S., Rabadzhiev, Y., Eller, M. R., Iliev, I., Ivanova, I., \& Santana, W. C. (2017). Microorganisms in Honey. In Honey Analysis. https://doi.org/10.5772/67262

Souza, B. de A., Marchini, L. C., Dias, C. T. dos S., Oda-Souza, M., Carvalho, C. A. L. de, \& Alves, R. M. de O. (2009). Avaliação microbiológica de amostras de mel de trigoníneos (Apidae: Trigonini) do Estado da Bahia. Ciência e Tecnologia de Alimentos, 29(4), 798-802. https://doi.org/10.1590/S010120612009000400015

Souza, B. de A., Marchini, L. C., Oda-Souza, M., Carvalho, C. A. L. de, \& Alves, R. M. de O. (2009). Caracterização do mel produzido por espécies de Melipona Illiger, 1806 (apidae: meliponini) da região nordeste do Brasil: 1. Características físico-químicas. Química Nova, 32(2), 303-308. https://doi.org/10.1590/S0100-40422009000200007

Tornuk, F., Karaman, S., Ozturk, I., Toker, O. S., Tastemur, B., Sagdic, O., ... Kayacier, A. (2013). Quality characterization of artisanal and retail Turkish blossom honeys: Determination of physicochemical, microbiological, bioactive properties and aroma profile. Industrial Crops and Products, 46, 124-131. https://doi.org/10.1016/j.indcrop.2012.12.042

Vrbova, L., Sivanantharajah, S., Walton, R., Whitfield, Y., Lee, C., Picard, I., Tataryn, J. (2018). Outbreak of Salmonella Typhimurium associated with feeder rodents. Zoonoses and Public Health, 65(4), 386-394. https://doi.org/10.1111/zph.12442 